\title{
PREFACE
}

In this period sensitivity to a new thing both in terms of cognitive, affective, and psychomotor will develop optimally and progressively. Therefore, the implementation of Basic Education must get special attention because it is an educational momentum that cannot be repeated. Basic Education still accommodates the implementation of the principles of the three student associations described by Ki Hajar Dewantara and government policies as formal, non-formal, and informal education. Basic education in the broadest sense and agreed upon by the community involves Early Childhood Education (PAUD), Elementary School Education (SD), and Junior High School Education. PAUD and SD studies are urgent studies but are rarely discussed in detail, because considering that PAUD and SD which are actually the backers of the implementation of basic education where basic education is the momentum of implementing one's education, a discussion forum is needed to exchange ideas between academics and practitioners in the form of national seminar named after the National Seminar on Elementary Education (SNPD) 2018. This seminar focuses on strategies to accelerate the Disruption Era, this is important because the era will always provide challenges to the development of Science and Technology which have a massive impact on education.

SNPD 2018 is an activity to share knowledge between academics and academics, academics with practitioners, and practitioners with practitioners. This activity was packaged in the form of a panel discussion by bringing in speakers from various backgrounds, namely academics, expert practitioners, and government policy makers. This activity was motivated by the demands of innovation needed to face the challenges of the era of the Disruption Era. The implementation of this seminar is expected to accelerate the world of education with innovations that are raised to face the existence of a disruption era that must be faced, and we as movers in the world of education both as academics and practitioners must work together to achieve a sustainable movement to realize a better quality Indonesian education. Able to face all challenges of the times.

Our thanks go to all leaders of Sebelas Maret University and the Teaching and Education Faculty who have supported the implementation of the 2018 SNPD activities carried out by the Early Childhood Teacher Education Study Program and Elementary School Teacher Education. Our gratitude also goes to all the committees who have made every effort to organize the SNPD 2018, and do not forget to express our gratitude and respect to all participants of the 2018 SNPD activities either as participants or as presenter.

Editor Proceeding SNPD 2018,

Prof. Dr. Retno Winarni, M.Pd.

Dr. Sri Marmoah, M.Pd.

Idam Ragil Widianto Atmojo, M.Si. 


\section{LIST OF COMMITTEE}

\section{Steering Commitee}

Chairperson:

Prof. Dr. Joko Nurkamto, M.Pd.

Advisory Boards and Scientific Committee:

1. Dr. Munawir Yusuf, M.Psi.

2. Dr. Imam Sujadi, M.Si.

3. Dr. Sapta Kunta Purnama, M.Pd.

4. Drs. Hadi Mulyono, M.Pd.

5. Warananingtyas Palupi, S.Sn., M.A.

6. Prof. Dr. St.Y Slamet, M.Pd.

7. Prof. Dr. H. Soegiyanto, S.U.

8. Prof. Dr. Retno Winarni, M.Pd

9. Dr. Sri Marmoah, M.Pd

10. Dr. Sukarno, M.Pd.

11. Dr. Siti Wahyuningsih, M.Pd.

12. Dr. Suharno, M.Pd.

13. Dr. Rukayah, M.Hum.

14. Dr. Hartono, M.Hum.

15. Dr. Riyadi, M.Si.

16. Dr. Peduk Rintayati, M.Pd.

17. Dr. Chumdari, M.Pd.

18. Idam Ragil Widianto Atmojo, M.Si.

19. Karsono, M.Sn.

\section{Organizing Commitee}

Chairperson:

Dr. Sri Marmoah, M.Pd.

Vice Chairperson:

Dr. Siti Wahyuningsih, M.Pd.

Secretarial staffs:

1. Idam Ragil Widianto Atmojo, S.Pd., M.Si.

2. Anesa Surya, S.Pd., M.Pd.

3. Dra. Siti Istiyati, M.Pd

Accomodation and Ceremony:

1. Dra. Yulianti, M.Pd.

2. Adriani Rahma Pudyaningtyas, S.Psi., M.A

Papers and Publication:

Nurul Kusuma Dewi, S.Pd., M.Pd

Website Development:

Karsono, S.Sn., M.Sn.

Logistic and Supporting Team:

Fadhil Purnama Adi, S.H., M.H. 


\section{SEMINAR PHOTOGRAPH}
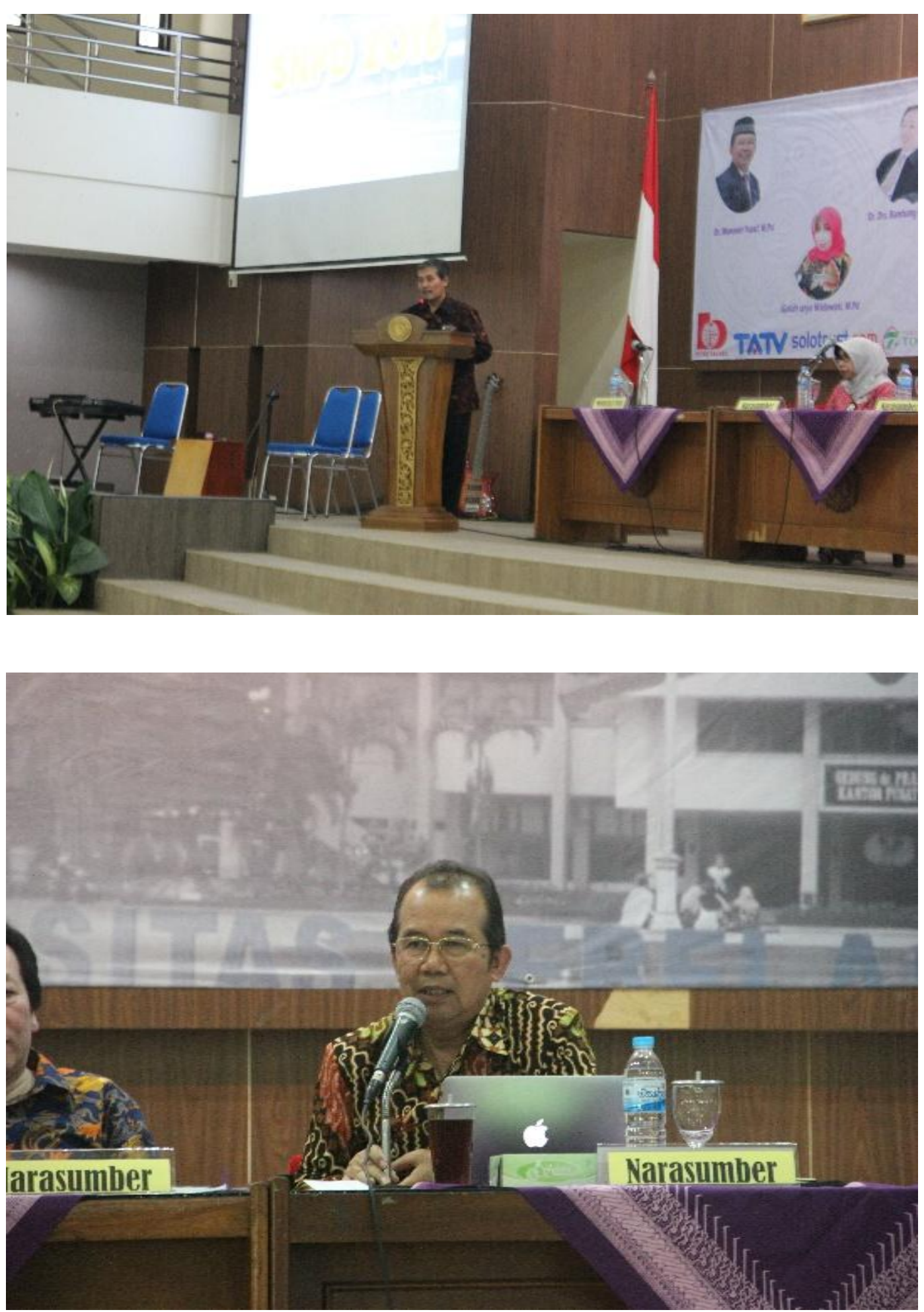

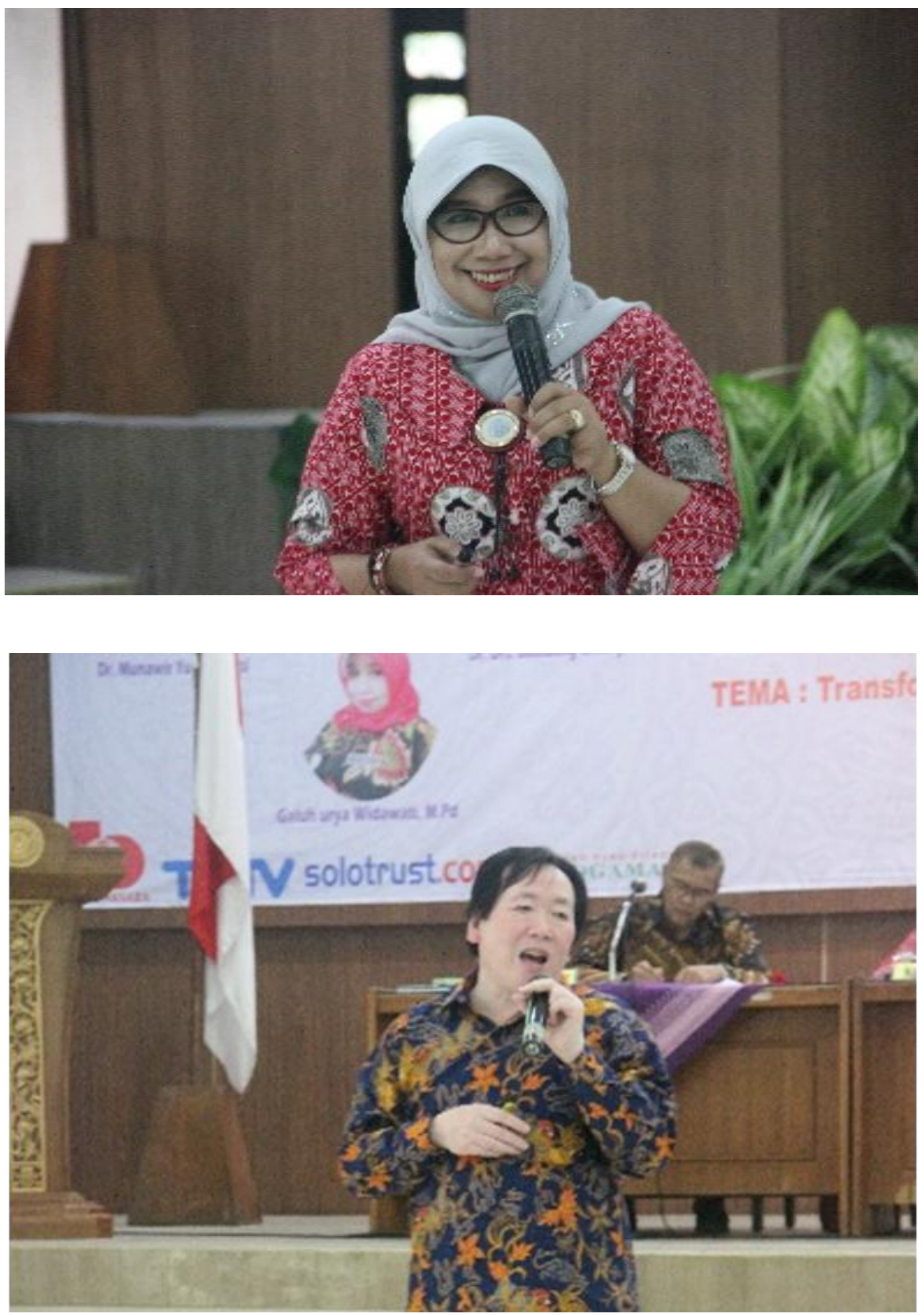

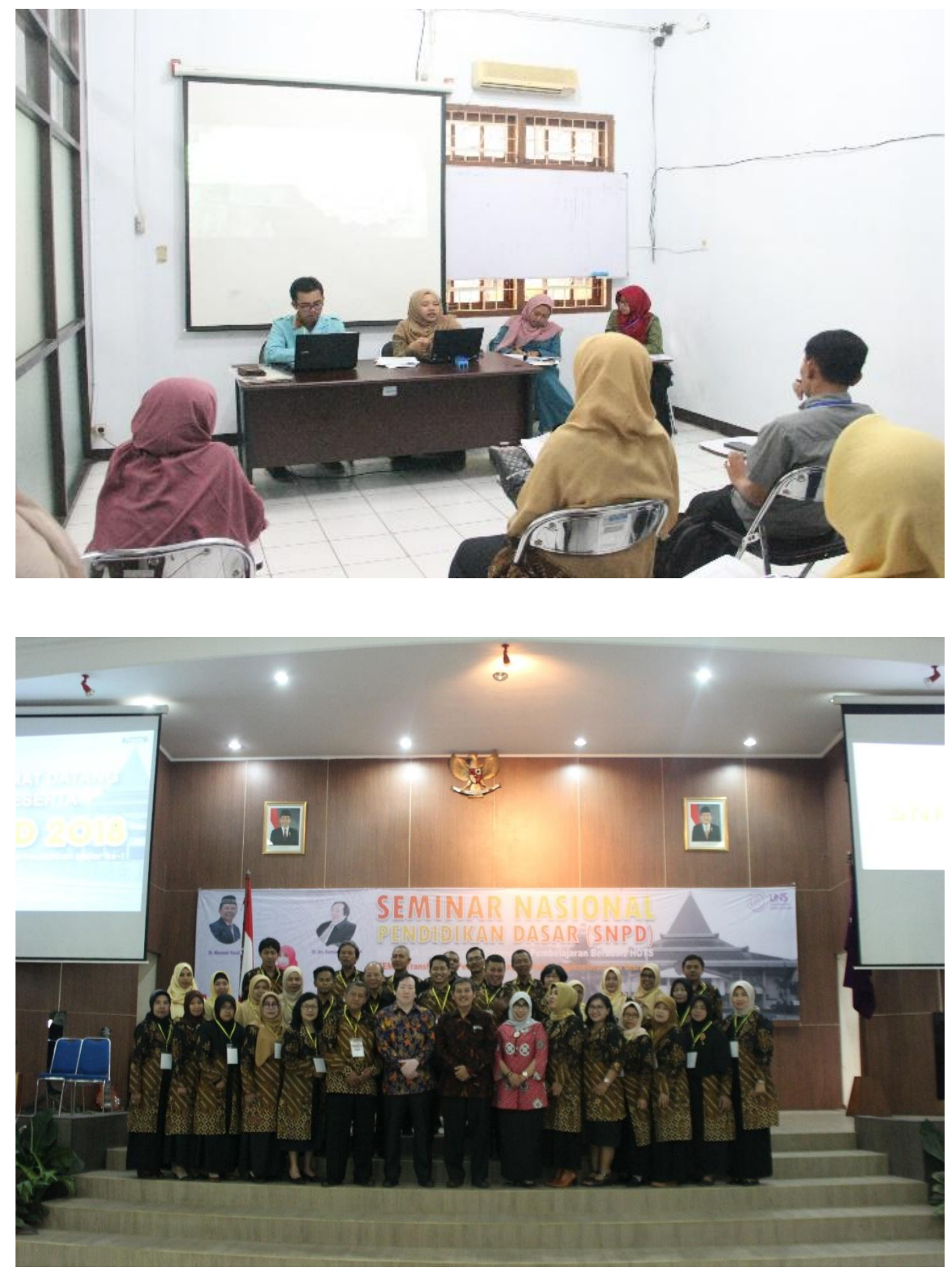


\section{PEER REVIEW STATEMENT}

All papers published in this volume of Social, Humanities, and Educational Studies (SHEs): Conference Series have been peer reviewed through processes administered by the proceedings Editors. Reviews were conducted by expert referees to the professional and scientific standards expected of a proceedings journal published by Universitas Sebelas Maret. 


\section{TABLE OF CONTENTS}

IMPLEMENTATION INTERNAL QUALITY ASSURANCE IN TERMS OF 1ELEMENTARY SCHOOL LEARNING PROCESS

Adik Rian Saputra

ECONOMICS STORY BOOK TO GIVE BASIC ECONOMIC RASIONALITY 10-17 FROM AN EARLY AGE

Aditya Dewantari, Eka Prayudhista

REWARD AND PUNISHMENT IN THE PERSPECTIVE OF BEHAVIORISM LEARNING THEORY AND ITS IMPLEMENTATION IN ELEMENTARY SCHOOL Ahmad Syawaludin, Sri Marmoah

IMPLEMENTATION OF CRITICAL THINKING THEORY IN LEARNING ACTIVITY AT PHILIPPINES ELEMENTARY SCHOOL

Amalia Ulfah, Hasan Mahfud, Karsono

FINDING HOTS-BASED MATHEMATICAL LEARNING IN ELEMENTARY SCHOOL STUDENTS

Anesa Surya, Sularmi, Siti Istiyati, Rahmat Fajar Prakoso

INTERACTIVE MULTIMEDIA USE TO INCREASE LEARNING INTEREST

Anggi Tiarasari, Sukarno, Sarwanto

THE IMPROVEMENT OF WRITING SKILL OF POETRY THROUGH COOPERATIVE INTEGRATED READING AND COMPOSITION (CIRC) MODEL

Annisa IImi Nurrani, Yulianti, Joko Daryanto

COMPARASION OF THE ANALYTICAL THINKING ABILITY IN THE SIMPLE MACHINE MATERIAL BETWEEN GUIDED INQUIRY LEARNING MODEL AND STUDENT TEAM ACHIEVEMENT STUDENT DIVISION (STAD) OF PRIMARY SCHOOL STUDENTS

Annis Maulia Fatimahtuzzahroh, Peduk Rintayati, Idam Ragil Widianto Atmojo

THE EFFECT OF DIRECTED READING THINKING ACTIVITY (DRTA) LEARNING STRATEGY AND READING INTEREST FOR READING COMPREHENSION ABILITY

Arini Itsna Annida, St. Y. Slamet, Retno Winarni

DEVELOPMENT OF INDONESIAN LANGUAGE SKILLS INSTRUCTIONAL MATERIALS BASED PROJECT BASED LEARNING WITH INQUIRY APPROACH

Arum Ratnaningsih, Titi Anjarini

THE DEVELOPMENT OF A WEB-BASED LEARNING TO IMPROVE A 77-84 CREATIVE WRITING ABILITY

Atikah Mumpuni, Laelia Nurpratiwiningsih

URGENCY OF PARTICIPATION OF PARENTS IN DEVELOPING POSITIVE CULTURE IN ELEMENTARY SCHOOLS

Atsani Rohmatun Nisa', Ratih Laila Istiqomah

IMPLEMENTATION OF HUMANISTIC APPROACHES FOR SOCIAL STUDIES IN ELEMENTARY SCHOOLS

Azhar Sulistiyono 
FEASIBILITY INDICATORS OF STUDY BOOKS USED ELEMENTARY SCHOOL

STUDENTS

Bayu Purbha Sakti

THE ENHANCEMENTS' SKILL OF WRITING POETRY BY PICTURE AND PICTURE DESIGN OF TREE GRADE STUDENTS AT MANGKUYUDAN NO.02 ELEMENTARY SCHOOL SURAKARTA IN THE ACADEMIC YEAR OF 2017/2018

Bekti Lestari, Retno Winarni, Suharno

THE ROLE OF PRINCIPAL IN CURRICULUM AND LEARNING MANAGEMENT Bening Sri Palupi, Ervina Esti

"ANGSA BIMO" (ANGKRINGAN SADAR HOBI MACA) CULTIVATE LITERACY CULTURE THROUGH METHOD CONTEST "ORTU NGACA" (CONTEST ORIGAMI, WRITE, RECITE, READ) ON STUDENT ELEMENTARY SCHOOL MENOREH SALAMAN

Betty Risma Darwiastuti, Suci Wulan Sari, Annis Ika Mayawati, Alif Rizki Yunanto, Chabib Oktafianjati, Galih Istiningsih

IMPROVEMENT OF LEARNING ACTIVITIES IN SCIENCE LEARNING THE FOURTH GRADE STUDENTS OF STATE ELEMENTARY SCHOOL THROUGH THE MODEL OF PREDICT OBSERVE EXPLAIN (POE)

Bety Permata Ningtyas, Hasan Mahfud, Karsono

OUTDOOR LEARNING MODEL TO DEVELP CREATIVE THINKING ABILITY IN WRITING POETRY

Cahyaning Oktaviani, St. Y. Slamet, Hartono

THE IMPLEMENTATION OF GALLERY WALK LEARNING MODEL TO IMPROVE VERBAL COMUNICATING SKILL OF PERFORMANCE RESULT THRU THEM ATIC LEARNING Candrika Sekar Pertiwi, Lies Lestari, Idam Ragil Widianto Atmojo

CHARACTER BASED INTERACTIVE MULTIMEDIA IN WRITING SHORTSTORY CLASS FOR PRIMARY SCHOOL GRADE 6

Cerianing Putri Pratiwi, Fauzatul Ma'rufah Rohmanurmeta

LISTENING SKILLS IN CHILDREN AGED 5-6 YEARS

Chrisma Arum Kartikadewi, Siti Wahyuningsih, Warananingtyas Palupi

THE IMPROVEMENT OF THE UNDERSTANDING OF THE STRUGGLE IN MAINTAINING INDONESIA'S INDEPENDENCE CONCEPT THROUGH EVERYONE IS A TEACHER HERE LEARNING MODEL SUPPORTED BY AUDIO VISUAL MEDIA

Citra Aulia Saputri, Siti Wahyuningsih, Sadiman

TEACHER MANAGEMENT OF INTEGRATED ISLAMIC ELEMENTARY SCHOOL IN BENGKULU PROVINCE

Citra Dewi

THE IMPROVEMENT OF THE UNDERSTANDING OF SERVICE AND FIGURE ROLE OF INDONESIAN INDEPENDENCE CONCEPT THROUGH TEAMS GAMES TOURNAMENT MODEL HELPED BY ROTAR MEDIA

Dede Eka Putri, Endang Sri Markamah, Sadiman 
IMPLEMENTATION OF ACADEMIC SUPERVISION MANAGEMENT IN 190-194 PRIMARY SCHOOL TO FACE THE DISRUPTION ERA

Desi Ratnasari, Roemintoyo, Winarno

IMPROVING PROBLEM-SOLVING SKILL IN PLANE FIGURE AND SOLID FIGURE ESSAY THROUGH THE ASSURANCE, RELEVANCE, INTEREST, ASSESSMENT, SATISFACTION (ARIAS) LEARNING METHODOLOGY

Desi Yulanda Putri, Retno Winarni, Anesa Surya

EYE AND FOOT COORDINATION CONTRIBUTION ON PASSING SKILLS IN FUTSAL ATLET AT SDIT IQRA BENGKULU

Desrio Windoro

ASSESSMENT OF AFFILIATED SOCIAL ATTITUDES BASED ON PEER AND SELF ASSESSMENT TECHNIQUES IN CURRICULUM 2013 FOR ELEMENTARY SCHOOL PARTICIPANTS

Dessy Nur Maulina, St. Y. Slamet, Mintasih Indriayu

EXPERIMENTS BASED OF TWO STAY TWO STRAY MODEL APPLICATION TO IMPROVE LEARNING OUTCOMES WATER CYCLE OF STUDENT ELEMENTARY SCHOOL

Dwi Nurpalupi Retnosari, Suharno, Peduk Rintayati

THE IMPLEMENTATION OF AIR (AUDITORY, INTELLECTUALLY, AND REPETITION) LEARNING MODEL BASES FLASHCARD MEDIA TO IMPROVE PROBLEM SOLVING SKILL OF PLANE GEOMETRY

Eka Agustina Khairunnisa, Riyadi, Hasan Mahfud

THE USEFULL OF AUGMENTED REALITY OVER THE NATIONAL INSIGHT IN LEARNING ERA DISRUPTION-BASED

Eliya Rochmah, Erna Labudasari, Nurani Amalia

DEVELOPING APPRECIATIVE LITERATURE TEXTBOOK BASED ON THEMATIC-INTEGRATIVE THROUGH ACTIVE LEARNING TO IMPROVE UNDERGRADUATE STUDENTS' APPRECIATIVE CAPABILITY ON POETRY AND DRAMA IN ELEMENTARY TECHER EDUCATION PROGRAM

Endang Sri Markamah, St. Y. Slamet, Rukayah, Retno Winarni

ENHANCING STUNDENT'S SCIENTIFIC ATTITUDE USING INQUIRY LEARNING MODELS FOR SCIENCE SUBJECT CLASSROOM IN 5TH GRADE STUDENT OF SD NEGERI PRAWIT I NO.69 YEAR OF ACADEMIC 2017/2018 Ermi Widyaningsih, Jenny Indrastoeti Siti Poerwanti, Chumdari

IMPLEMENTATION OF PRINCIPAL SUPERVISION IN PRIMARY SCHOOL Etika Kusumawarti, Hariyatunnisa Ahmad

DONGENG ORIGINAL NUSANTARA (DANA) BASED ON STORY BASED LEARNING (SBL) TO IMPROVE THE ABILITY OF TEACHER TEACHERS IN SURAKARTA

Fadhil Purnama Adi, Hadi Mulyono, Idam Ragil Widianto Atmojo, Roy Ardiansyah

IMPLEMENTATION OF THINK TALK WRITE (TTW) MODEL TO IMPROVE POETRY WRITING SKILL ON FOUR GRADE STUDENT

Febi Sulistyo Rini, Muhammad Ismail Sriyanto, Idam Ragil Widianto Atmojo 
IMPLEMENTATION OF TEAMS GAMES TOURNAMENT (TGT) MODEL TO IMPROVE MOTIVATION IN LEARNING MATHEMATICS

Fitriastuti, Siti Kamsiyati, Karsono

NUTRITIONAL BEHAVIOR PATTERNS IN PROGRAM OF GIVING ADDITIONAL FOODS FOR INFANTS AGED 0-3 YEARS OF UNDER RED LINE

Frida Yunita Sari, Sri Hilmi Pujihartati

THE ENHANCEMENTS SKILL OF WRITING POETRY BY DWA (DIRECTED WRITING ACTIVITY) STRATEGY

Galuh Lukitasari, Siti Wahyuningsih, Tri Budiharto

THE CONTEXTUAL TEACHING AND LEARNING MODEL USAGE TO IMPROVE SCIENCE ATTITUDE IN SCIENCE'S LEARNING OF STUDENT CLASS V PUBLIC ELEMENTARY SCHOOL OF MANGKUBUMEN KULON NO. 38 SURAKARTA

Ganing Widarwati, Peduk Rintayati, Chumdari

IMPLEMENTATION OF STORY TELLING USING PUPPET TO IMPROVE STUDENTS' LISTENING OF TALES ABILITY

Gias Rima Dhewi Laksmita Dianasari, Retno Winarni, Karsono

IMPROVING ABILITY TO SPEAK THROUGH ROLE PLAYING ACTIVITIES IN STUDENTS OF TK PERTIWI NAMBANGAN I SELOGIRI

Heni Amrih Laksmita Dewi

RECRUITMENT MANAGEMENT OF EDUCATORS AT THE STATE ELEMENTARY SCHOOL OF SINDUADI 1 SLEMAN YOGYAKARTA

Heni Nurhayanti, Ismi Fadila

APPLYING OF NUMBERED HEAD TOGETHER LEARNING MODEL ON EIGHT THEMES MY PLACE AREA TO IMPROVE SOCIAL ATTITUDE OF FOURTH GRADE STUDENT IN STATE-PRIMARY SCHOOL 1 TEGALGONDO KLATEN AT 2017/2108 ACADEMIC YEAR.

Hening Damantari, Chumdari, Siti Wahyuningsih

IMPROVED OF THE ENVIRONMENT CARE ATTITUDE ON SCIENCE LEARNING BY APPLYINGTHE SCIENCE ENVIRONMENT TECHNOLOGY AND SOCIETY (SETS) MODEL

Husnul Khotimah, Hadi Mulyono, Anesa Surya

IMPROVING MATHEMATICAL PROBLEM SOLVING SKILL THROUGH THE APPLICATION COOPERATIVE LEARNING MODEL OF THINK TALK WRITE (TTW) TYPE IN STUDENT GRADE V ELEMENTARY SCHOOL (Classroom Action Research on Grade V Students of SD N Pajang 2 No. 171 Surakarta 2017/2018 Academic Year)

lis Dian Veramita, Hadi Mulyono, Riyadi

IMPLEMENTATION OF EDUCATION PLANNING IN IMPROVING EDUCATIONAL QUALITY THROUGH 2013 CURRICULUM BASIC SCHOOL Ima Hariyanti Ningsih, Retno Winarni, Roemintoyo

IMPROVEMENT OF LISTENING SKILL ON SHORT STORIES BY APPLYING MIND MAPPING

Intan Kustyarini, Hadi Mulyono, Fadhil Purnama Adi 
INDONESIAN HUMAN RIGHTS POLITIC IN A RESTORATIVE JUSTICE CONCEPT

Irsyad Dhahri Samad

THE IMPACT OF COOPERATIVE LEARNING TYPE MAKE A MATCH TEACHING MODEL TOWARD UNDERSTANDING SAINS CONCEPT IN THE REVIEW OF LEARNING MOTIVATION IN ELEMENTARY SCHOOL Istabiqul IIma, Kartono, Anesa Surya

DISRUPTION AND IMPLEMENTATION OF INNOVATIVE LEARNING MODELS AND MEDIA ON READING AND WRITING JAVANESE ALPHABET IN ELEMENTARY SCHOOL

Joko Daryanto

APPLICATION OF NATURAL ENVIRONMENT APPROACHES TO IMPROVE SCIENCE PROCESS SKILLS IN ELEMENTARY SCHOOL STUDENTS

Laksmi Evasufi Widi Fajari, Joharman, Moh Salimi

IMPROVED CRITICAL THINKING SKILLS ON SCIENCE LEARNING BY APPLLYNG THE PREDICT, OBSERVE, EXPLAIN (POE) MODEL

Larasati, Jenny Indrastoeti Siti Poerwanti, Anesa Surya

THE IMPROVEMENT OF THE UNDERSTANDING OF THE STRUGGLE OF THE WARRIORS IN THE DUTCH COLONIAL PERIOD THROUGH TEAMS GAMES TOURNAMENT (TGT) LEARNING MODEL ON STUDENTS OF V GRADE SD N SURAKARTA ACADEMIC YEAR 2017/2018

Latifah Aulia Harini, Hartono, Hadiyah

APPLICATION OF VISUALIZATION, AUDITORY, KINESTETHIC (VAK) LEARNING MODEL FOR INCREASING UNDERSTANDING ENERGY CONCEPT

Latifah Nur Khasanah, Hadi Mulyono, Retno Winarni

THE ENHANCEMENT OF UNDERSTANDING CONCEPT OF FORCE THROUGH PREDICT OBSERVE EXPLAIN (POE) MODEL

Lelyta Anggraeny, Peduk Rintayati, Muhammad Shaifuddin

THE IMPROVEMENT OF THE CURSIVE HANDWRITING SKILL THROUGH EXPLICIT INSTRUCTION MODEL (A CLASSROOM ACTION RESEARCH OF THE SECOND GRADE STUDENTS OF STATE PRIMARY SCHOOL SOROPADAN NO, 180 SURAKARTA IN ACADEMIC YEAR 2017/2018)

Linda Fitrianti, Sadiman, Matsuri

IMPROVED NARRATIVE WRITING SKILLS BY APPLLYNG THE COOPERATIVE LEARNING MODEL CONCEPT SENTENCE TYPE WITH SERIES PICTURE MEDIA

Linda Margiyan, Rukayah, Hadi Mulyono

THE IMPROVEMENT OF EXPERIMENTAL SKILLS BY IMPLEMENTING PREDICT, OBSERVE, EXPLAIN (POE) LEARNING MODEL IN LEARNING SCIENCE

Linda Pradina Candra, Peduk Rintayati, Jenny Indrastoeti Siti Poerwanti 
EARLY CHILDHOOD LITERACY

Mainita Elisnawati, Warananingtyas Palupi, Nurul Kusuma Dewi

POP-UP CARDS FOR EARLY CHILDHOOD LEARNING

Marlina Shinta Putri, Siti Wahyuningsih, Ruli Hafidah

APPLICATION OF SOMATIC AUDITORY VISUALIZATION INTELLECTUALLY LEARNING STYLE TO IMPROVE THE UNDERSTANDING OF THE CONCEPT OF STRUGGLE TO MAINTAIN INDEPENDENCE

Marlita Pramuharti, Hartono, Kuswadi

THE IMPLEMENTATION OF COOPERATIVE LEARNING TYPE THINK PAIR SHARE MODEL TO IMPROVE READING COMPREHENSION SKILL IN DISRUPTION ERA

Maullana Latief, Muhammad Ismail Sriyanto, Joko Daryanto

CHILDREN'S FRIENDLY EDUCATION BASED ON TRADITIONAL GAMES IN TAMAN MUDA IBU PAWIYATA ELEMENTARY SCHOOL

Maya Kartika Sari, Suminto A. Sayuti, Pardjono

THE EFFECT OF SURVEY, QUESTION, READ, RECITE, AND REVIEW (SQ3R) TEACHING METHOD AND READING INTEREST TOWARD READING COMPREHENSIONS OF CHILDREN STORIES ABILITY (EXPERIMEN RESEARCH IN THE $5^{\text {th }}$ GRADE OF ELEMENTARY SCHOOL AT LAWEYAN DISTRICTS SURAKARTA IN THE SCHOOL YEAR 2017/2018

Miftakhul Husna, St. Y. Slamet, Jenny Indrastoeti Siti Poerwanti

DEVELOPMENT OF THEATER EDUCATION TEKSBOOK WITH CHARACTER EDUCATION AND LOCAL WISDOM THROUGH ACTIVE LEARNING TO IMPROVE THE STUDENTS SCRIPT WRITING ABILITY

Muhammad Ismal Sriyanto, Retno Winarni

THE IMPLEMENTATION OF THE 21TH CENTURY COMPETENCY FOR ELEMENTARY SCHOOL TEACHERS AT CURRICULUM 2013 TRAINING CENTRAL JAVA PROVINCE YEAR 2017

Mulida Hadrina Harjanti

IMPROVED OF THE EXPERIMENTING SKILL BY GUIDED INQUIRY LEARNING MODEL ON SCIENCE LEARNING

Nanda Sari Rizki, Kartono, Hadiyah

TEACHERS NEED NEURO-TEACHING SKILLS IN THE CLASSROOM : A NEW PERSPECTIVE FOR BETTER FUTURE IN EDUCATION

Nani Restati Siregar, Mansyur M., Muhammad Ilham

$487-494$

$495-500$

$501-507$

$508-522$

LEADERSHIP OF PRINCIPAL DEVELOPING LEARNING ORGANIZATION IN SD NEGERI BULUKANTIL SURAKARTA

Nenik Hidayah

THE APLICATION OF PLAYING BASED ON REGGIO EMILIA'S 555-561 APPROACH TO STIMULATE EARLY CHILDHOOD CREATIVITY

Novita Eka Nurjanah, Yetty Isna Wahyuseptiana

CHANGES IN THE ROLE OF TEACHERS IN IT-BASED MATHEMATICAL 562-567 LEARNING IN DISRUPTION ERA

Novy Trisnani 
THE IMPLEMENTATION OF COOPERATIVE LEARNING MODEL OF 568-574 CONCEPT SENTENCE TO IMPROVE PANTUN SKILL WRITING

Nur Esti Handayani, Endang Sri Markamah, Muhammad Ismail Sriyanto

MOTIVATION IN SOCIAL SCIENCE LEARNING IN DIGITAL ERA: CASE 575-583 STUDY OF MULTIMEDIA USE

Nur Fadhilah, Dhea Adela

ENTREPRENEURSHIP MANAGEMENT AT PRIMARY SCHOOL

Nur Indah Lailya Mawar Sari, Syahrul Nursianawati

'ENAK' BALL AS A ENVIRONMENTALLY FRIENDLY MULTISENSORIAL GAME TOOLS

Nurul Fadhilah, Yuyun Rahmawati, Wahyuni Novitasari, Faisal Khamdani

APPLICATION OF LEARNING CELL STRATEGY TO IMPROVE POSING QUESTION IN SOCIAL STUDIES

$598-604$

Nurul Hidayati, Siti Wahyuningsih, Hadiyah

IMPROVEMENT OF KNOWLEDGE ABILITY ABOUT ECONOMIC ACTIVITIES THROUGH THE GROUP INVESTIGATION MODEL

Peduk Rintayati, Arif Nofa Sugiyanto

LEARNING MOTIVATION OF SLOW LEARNER IN ELEMENTARY SCHOOL

Pratia Amdany, Sularmi, Muhammad Ismail Sriyanto

613-618

STUDY EXPLORATION THEMATIC LEARNINGBASED ON LOCAL WISDOM OF CENTRAL JAVA ON FOURTH GRADE OF ELEMENTARY SCHOOL

Priskila Dwinando Marindasari, Sri Marmoah, Sri Yamtinah

IMPROVEMENT OF POETRY WRITING SKILL THROUGH AUDITORY, INTELLECTUALLY, REPETITION (AIR) BASED ON OUTDOOR STUDY (Classroom Action Research of Third Grade at SD Negeri Soropadan No. 108 Surakarta Academic Year 2017/2018)

Proborini, Retno Winarni, Lies Lestari

"BENTHIK" TRADITIONAL GAME TO IMPROVE THE ABILITY OF ADDITION NUMBER

Rafika Said, Suyanto

THE EFFECT OF LEARNING MODEL PICTURE AND PICTURE AND READING INTEREST TOWARD STUDENTS' POETRY WRITING SKILLS OF $5^{\text {TH }}$ GRADE PRIMARY SCHOOL STUDENTS

Resti Audina, St. Y. Slamet, Jenny Indrastoeti Siti Poerwanti

DEVELOPMENT OF INDONESIAN LANGUAGE LEARNING TEXTBOOK WITH CHARACTER EDUCATION THROUGH ACTIVE LEARNING

$605-612$ AS AN ELEMENTARY STUDENTS' LEARNING SOURCE

Retno Winarni, St. Y. Slamet

IMPROVEMENT OF READING COMPREHENSION SKILLS OF CHILDREN'S STORY TRHOUGH APPLYING OF THINK PAIR SHARE LEARNING MODEL

Reza Fachrudin Zuhdi, Rukayah, Kuswadi

THE IMPORTANCE OF STIM-HOTS AND CRITICAL THINKING SKILL IN DISRUPTION ERA

Riky Rivaldi Pratama, Rizky Ardhia Pramesti 
APPLICATION OF GARDENING PROJECT IN KINDERGARTEN

Riska Puspaningrum, Anayanti Rahmawati, Nurul Kusuma Dewi

EFFORT TO IMPROVE CONCEPTUAL UNDERSTANDING OF NATURAL RESOURCE-RELATED ECONOMIC ACTIVITIES THROUGH THE APPLICATION OF CIRCUIT LEARNING MODEL

Riski Fitriana Sativa, Soegiyanto, Sadiman

IMPLEMENTATION OF INTERACTIVE MULTIMEDIA LEARNING BASED ON COGNITIVE LOAD THEORY IN GRADE 5 STUDENTS OF ELEMENTARY SCHOOL

Rissa Prima Kurniawati, Fida Rahmantika Hadi, Vivi Rulviana

THE USE OF INTERACTIVE MULTIMEDIA IN LEARNING BASED ON DISRUPTION ERA AT ELEMENTARY SCHOOL

Rizki Widyawulandari, Sarwanto, Mintasih Indriayu

CLASSROOM READING HELPED PROGRAMS FOR COMIC MEDIA TO IMPROVE THE INTEREST OF READING BASIC SCHOOL STUDENTS

Rohmah Suciningrum

IMPROVING FRACTION OPERATION SKILLS OF MULTIPLICATION AND DIVISION THROUGH THE APPLICATION OF DOMINO CARD TO STUDENT OF GRADE V SDN 02 PULOSARI ACADEMIC YEAR 2017/2018

Rohmatul Putri Retnowati, Siti Kamsiyati, Matsuri

IMPLEMENTATION OF NUMBERED HEADS TOGETHER (NHT) MODEL BASED ON AUDIO VISUAL MEDIA TO IMPROVE CONCEPTS COMPREHENSION OF COOPERATIVE

Rokhmah Dwi Arsitarasmi, Sadiman, Hadiyah

THE PRACTICE OF CITY RESIDENTS IN INFORMALITY RIVERBANKS WINONGO YOGYAKARTA CITY

Rosesynta Paramita, Akhmad Ramdhon

THEMATHIC LEARNING MODEL AND ITS EFFECT ON STUDENTS' LEARNING MOTIVATION (Case Study at Nature Elementary School of Baturraden)

Safinatun Najah, Ngatman, Moh Salimi

INCULCATE CRITICAL THINKING SKILLS IN PRIMARY SCHOOLS

$688-696$

Salvina Wahyu Prameswari, Suharno, Sarwanto

THE INFLUENCE OF USING AUDIOVISUAL MEDIA AND LEARNING MOTIVATION OF CHILDREN STORIES WRITING ABILITY

Salwaa Nadiya Alif, St. Y. Slamet, Yulianti

THE IMPLEMENTATION OF SAVI MODEL WITH ECLIPSE CROSSWORD TO IMPROVE STUDENTS' ACTIVITIES AND LEARNING ACHIEVEMENT OF CUBE ROOTS FOR GRADE VI SEMESTER I IN STATE ELEMENTARY SCHOOL I SANAN, GIRIMARTO DISTRICT, WONOGIRI REGENCY IN THE YEAR 2017/2018

Samsi Suryanjani, Riyadi, Budi Usodo

MULTILITERATION LEARNING IN WRITING ENGLISH DESCRIPTIVE TEXT THROUGH COLLABORATIVE TECHNIQUES - (THEORITICAL REVIEW) 
IMPLEMENTATION OF COOPERATIVE LEARNING MODEL TYPE MAKE A MATCH TO IMPROVE CONCEPTS COMPREHENSION OF TWO DIMENTIONAL FIGURE CHARACTER

Santri Prabowo Utomo, Sukarno, Muhammad Ismail Sriyanto

DEVELOPMENT OF CURRICULUM BASED ON THE LOCAL WISDOM

Septiana Agustin

THE IMPROVEMENT OF THE INTERESEST IN LEARNING SOCIAL SCIENCES USING JOYFUL LEARNING STRATEGY SUPPORTED BY FUN SOCIAL PUZZLE MEDIA

Sifa Adriani Prihatina, Sukarno, Endang Sri Markamah

SUBJECT SPECIFIC PAEDAGOGIC (SSP) BASED ON HIGHER ORDER THINKING SKILL (HOTS) TO IMPROVE THE ABILITY OF SD TEACHERS IN SURAKARTA

Siti Istiyati, Kartono, Idam Ragil Widianto Atmojo

SMART: SOLUTIONS FOR LOW ENTREPRENEURSHIP STUDENTS IN A DISRUPTION ERA

Siti Kamsiyati, Idam Ragil Widianto Atmojo

POTENTIAL CONTENT OF ENERGY MATERIAL FOR EMPOWERING ENVIRONMENTAL AWARENESS IN SCIENCE LESSON IN ELEMENTARY SCHOOL TEACHER CANDIDATE

Siti Patonah, Sentot Budi Rahardjo, Cari, Sajidan

IMPLEMENTATION OF AMONG SYSTEM A3 (ASAH, ASIH, ASUH) IN PLANTING THE VALUE OF CHARACTERS IN EARLY CHILDHOOD

Siti Wahyuningsih, Nurul Kusuma Dewi, Ruli Hafidah

DEVELOPMENT OF PERSONALITY COMPETENCE OF PRESERVICE TEACHER AT DISRUPTION ERA

Siti Zumrotul Maulida, Ifah Silfianah, Ainun Nikmati Laily

IMPLEMENTATION OF EDUCATIONAL NATIONAL STANDARD POLICY ON THE OPERATION OF BASIC EDUCATION (Case Study in Wajo District, South Sulawesi)

Sitti Aminah, Imran Ismail

THE IMPROVEMENT ABILITY OF CALCULATING DIVISION USED UNO CARD IN MATHEMATIC

Solikhatul Putri Amelia,Sukarno,Siti Wahyuningsih

DIGITAL AGE LITERACY FOR INDONESIAN ELEMENTARY SCHOOL 849-855 STUDENT

Soufi Dianimdri, Wahyu Dwi Yuliani

CONNECTION BOOK AND WORKSHEET BASED 2013 CURRICULUM FOR ELEMENTARY TEACHERS IN SURAKARTA

Sri Marmoah, Soegiyanto, Idam Ragil Widianto Atmojo, Roy Ardiansyah

DEVELOPING TEXT-BASED AND CHARACTER-BASED INDONESIAN TEXTBOOK THROUGH ACTIVE LEARNING TO IMPROVE THE SCIENTIFIC WRITING SKILL

St. Y. Slamet, Retno Winarni, Hartono 
THE IMPROVEMENT OF OBSERVATION REPORT WRITING SKILL THROUGH

THE APPLICATION OF EXPERIENTIAL LEARNING MODEL (CLASSROOM ACTION RESEARCH IN THE FIFTH GRADE STUDENTS OF SURAKARTA STATE PRIMARY SCHOOL AT 2017/2018 ACADEMIC YEAR

Sulistya Ardiani Kusumastuti, Yulianti, Endang Sri Markamah

IMPROVEMENT OF LISTENING SKILL THROUGH DIRECTED LISTENING THINKING ACTIVITY (DLTA) LEARNING STRATEGY

Susanti Fuji Rahayu, Sukarno, Sularmi

PENGEMBANGAN MODUL PEMBELAJARAN SAINS BERBASIS KEARIFAN LOKAL DAERAH NGAWI PADA TAMAN KANAK-KANAK

Susdarwati, Degi Alrinda Agustina

TRAINING AND USE OF INTERACTIVE POWER POINTS IN NATURAL EVENT MATERIAL FOR TEACHER PRIMARY SCHOOL AT MUHAMMADIYAH 1 PURWOREJO

Titi Anjarini, Galih Yansaputra

CHILDREN'S FRIENDLY EDUCATION THROUGH THE "MORNING STORY" SCHOOL CULTURE AS AN EFFORTS TO STRENGTHEN STUDENT CHARACTERS IN SD 01 KANIGORO MADIUN

Titin Kuntum Mandalawati

DIMENSIONS OF EDUCATION MANAGEMENT (LAW AND PROFESSINAL)

Tri Aska Wijayanti, Suharno, Sri Yamtinah

CREATIVE THINKING SKILL AS AN IMPORTANT ASPECT IN DISRUPTIVE ERA

Tri Yuda Bekti Pamungkas, Restu Peni Winahyu

HIGHER ORDER THINGKING (HOT) PROBLEMS TO DEVELOP CRITICAL THINKING ABILITY AND STUDENT SELF EFFICACY IN LEARNING MATHEMATICS PRIMARY SCHOOLS

Triana Jamilatus Syarifah, Budi Usodo, Riyadi

INCREASING ABILITY TO SOLVE MATH WORD PROBLEM THROUGH LOGAN AVENUE PROBLEM SOLVING (LAPS-HEURISTIK) LEARNING

Umi Rofi'atul Mahmudah, Retno Winarni, Tri Budiharto

IMPROVEMENT OF ABILITY TO SOLVE STORY PROBLEM ON FRACTIONS THROUGH THE APPLICATION OF COOPERATIVE LEARNING MODEL TYPE THINK PAIR SHARE

Venny Noermalita Sari, Siti Kamsiyati, Muhammad Shaifuddin

THE IMPROVEMENT OF OBSERVATION REPORT WRITING SKILL THROUGH THE APPLICATION OF THINK PAIR SHARE LEARNING MODEL

Widya Atika, Sukarno, Siti Wahyuningsih

MPROVEMENT OF JAVANESE SCRIPT WRITING SKILL THROUGH THE COOPERATIVE LEARNING MODEL OF FLANNELGRAPH MEDIA-AIDED THINK TALK WRITE (TTW) TYPE (A CLASSROOM ACTION RESEARCH TO THE STUDENTS IN GRADE IVA OF STATE PRIMRY SCHOOL 03 OF KARANGANYAR IN ACADEMIC YEAR 2017/2018)

Winda Dwi Astuti, Soegiyanto, Sukarno 
DEVELOPING RELATIONSHIP OF TEACHERS AND STUDENTS THROUGH SNAP DIARY AS A CHILDREN'S FRIENDLY SCHOOL SUPPORT IN ELEMENTARY SCHOOL

Wulan Tri Puji Utami

REALISTIC MATHEMATIC EDUCATION CAN IMPROVE THE UNDERSTANDING OF THE CONCEPT OF MATHEMATIC LESSONS IN ELEMENTARY SCHOOL

Yeni Dwi Kurino

INVESTMENT OF CHARACTER VALUES CARE ENVIRONMENT IN LEARNING 968-976 SCIENCE SOCIAL KNOWLEDGE BASED AUDIO VISUAL

Yonaka Adventa

THE IMPROVEMENT OF SKILL IN QUESTIONING THROUGH THE APPLICATION OF LEARNING STARTS WITH A QUESTION STRATEGY

Yuniarti, Sukarno, Sularmi

PRODUCT PERFORMANCE ASSESSMENT IN 2013 CURRICULUM FOR ELEMENTARY SCHOOL STUDENTS

Yuyun Dwi Haryanti

DEVELOPMENT PROCESS OF PRODUCT ASSESSMENT ON $992-997$ COURSES OF JAVANESE LANGUAGE FOR ELEMENTARY SCHOOL Endang Sri Maruti, Naniek Kusumawati

CREATIVE THINKING: REVIEWED FROM INFORMATION 998-1004 PROCESSING MODEL (IPM) FOR PRIMARY SCHOOL TEACHERS Idam Ragil Widianto Atmojo, Sajidan, Widha Winarno, Ashadi 